\title{
ZAGADNIENIE INTEGRACJI TEOLOGII MORALNEJ
}

Integracja określonej dziedziny naukowej i nadanie jej charakteru spójnej całości staje się zadaniem w dwóch różnych momentach rozwoju nauki. Zadanie to zjawia się przede wszystkim w momencie, gdy nagromadzony w określonej dziedzinie materiał badawczy ujawnia specyficzny charakter uzyskanej wiedzy i skłania do traktowania jej jako tworzywa nauki nowej, odrębnej od tej, w ramach której badania były podjęte.

Taka nowa dziedzina naukowa, mająca pierwotnie postać jedynie luźno powiązanych informacji i prób ich wyjaśnienia, przekształca się stopniowo w odrębną naukę. Dokonuje się to przy współudziale refleksji metodologicznej, która zapoczątkowuje i podtrzymuje proces integracji nowej nauki. Proces ten polega na wydzieleniu odpowiednich informacji i zagadnień z terenu jednej lub kilku nauk mniej wyspecjalizowanych i prowadzi do stworzenia całości w zasadzie jednorodnej, obejmującej informacje i zagadnienia bardziej specjalne, właściwe powstającej nauce. $Z$ rozproszonych pierwotnie, fragmentarycznych informacji powstaje wiedza uporządkowana. Krystalizuje się bowiem i stopniowo znajduje świadome uznanie określony aspekt badanego przedmiotu, ujmowanego dotychczas w sposób bardziej ogólny i wieloaspektowy ${ }^{1}$.

Integracja staje się jednak zadaniem również na dalszych etapach rozwoju określonej nauki. Dzieje się tak wówczas, gdy okazuje się, że przedmiot badań ze swej natury, lub z pewnych względów praktycznych,

1 „Uporządkowanie” polega $\mathrm{z}$ jednej strony na ustalaniu logicznej zależności (wynikania) zdań tworzących naukę, z drugiej zaś strony na segregacji zdań według aspektu, w jakim ujmują one przedmiot, którego dotyczą. Wiąże się to z pođstawową cechą poznania, określaną jako ,aspektowość”, wynikającą z możności ujmowania przedmiotu w akcie poznania nie całościowo, wyczerpująco - lecz tylko z określonego punktu widzenia, czyli w określonym aspekcie. 
wymaga ujmowania go w kilku aspektach jednocześnie, przy czym żaden $\mathrm{z}$ nich nie może być wyodrębniony jako podstawa dla tworzenia nauki nowej, lecz wszystkie te aspekty łącznie tworzą dopiero punkt wyjścia nauki o danym przedmiocie ${ }^{2}$.

Ujawnienie się takiego stanu rzeczy zmusza do poszukiwania aspektu nadrzędnego, integrującego naukę na nowych zasadach. Dopóki nie zostanie to osiagnięte, nie jest możliwe przedstawienie całokształtu wiedzy związanej z danym przedmiotem w sposób właściwy, logicznie uporządkowany, a jednocześnie dla danego przedmiotu odpowiedni. Nauka w takim momencie ujawnia brak wewnętrznej jedności. Odnalezienie tej jedności umoźliwia danej nauce odzyskanie rangi nauki dojrzałej oraz - co ma bardziej istotne znaczenie - przywraca pełną wartość wynikom uzyskanym na jej terenie. Wyniki bowiem uzyskiwane dotąd w badaniach prowadzonych różnymi metodami, w aspektach dla danej dziedziny nieswoistych, były narażone na szkodliwą jednostronność, a nawet mogły zawierać deformację samego przeảmiotu, którego dotyczyły. Odnosi się to w szczególności do tych dziedzin, których przedmiotem jest rzeczywistość humanistyczna - czlowiek w różnorodnych przejawach istnienia i działania ${ }^{3}$. Specjalne znaczenie ma proces wtórnej integracji w naukach praktycznych, ujmujących z konieczności działalność ludzką w wielu aspektach ${ }^{4}$.

$2 \mathrm{~W}$ badaniach naukowych rezygnuje się niekiedy świadomie $\mathrm{z}$ dokladnego wydzielenia ich zakresu i ujmowania przedmiotu $\mathrm{z}$ jednego okreslonego punktu widzenia. W wielu dyscyplinach, takich zwłaszcza, jak różnego rodzaju technologie, jest to podyktowane najczęściej dążeniem do uzyskania określonego produktu (przemysłowego, rolnego itd.), wytwarzanego na drodze procesów dotychczas niedostatecznie poznanych, a należących do zakresu różnych nauk (chemia, fizyka, biologia itp.). $\mathrm{Z}$ reguły jednak $\mathrm{w}$ stosunku do określonej dziedziny jako nauki - zwłaszcza ,czystej”, a nie stosowanej — stawiane jest wymaganie ścisłego określenia właściwego jej aspektu.

3 Wplyw koncepcji samej nauki na obraz człowieka, jaki dzięki tej nauce powstaje, można dostrzec na przykład $w$ związku $z$ przemianami zachodzącymi W sposobie pojmowania socjologii. Poảobną zależność wskazuje się także w badaniach historycznych.

4 Wiąże się to z ujawnieniem sie coraz to nowych aspektów działania człowieka, a także coraz to innych potrzeb spolecznych i coraz bardziej skomplikowanych zadań do rozwiązania. Tendencja do koncentracji badań różnoaspektowych jest zresztą wskazana jako zjawisko ogólne, prowadzące do integracji nauki jako całości: „Rozwój nauki szedł i w dalszym ciągu zmierza w kierunku coraz większej specjalizacji. W miarę doskonalenia sposobów postępowania badawezego i wzrostu wiedzy o przedmiocie badanym tworzą się nowe dyscypliny. Wszakże równolegle z procesem różnicowania postępuje proces integracji nauki. Proces ten odbywa się nie tylko na drodze sumowania wiedzy uzyskanej $w$ badaniach specjalnych (...) $\mathrm{Na}$ obszarach stykowych powstają dyscypliny wkraczające na teren gałęzi nauki nawet bardzo od siebie odleglych. Coraz też bardziej gruntuje się przekonanie, że wlaśnie na pograniczu nauk szczegółowych wypływają najdonioślejsze problemy, że tutaj dokonywane są największe odkrycia naukowe", W. Moszczeńska, Metodologii historii zarys krytyczny, Warszawa, 1968, s. 24. Szczególnej jednak doniosłości nabiera integracja wewnątrz określonej dziedziny naukowej, gdy jest podyktowana nie względami praktycznymi i nadzieją na uzyskanie nowych wyników, lecz względami zasadniczymi, to jest ujawniająca się natura samego badanego przedmiotu. 
$\mathrm{Na}$ terenie nauk teologicznych sygnalizowana jest od dłuższego czasu potrzeba wtórnej integracji w odniesieniu do teologii moralnej ${ }^{5}$. Dyscyplina ta, traktowana już tradycyjnie jako nauka odrębna, uformowana została jako dział lub część teologii. Jej koncepcja w związku z tym była uzależniona od koncepcji teologii w ogóle $\mathrm{i}$ wraz $\mathrm{z}$ nią ulegała pewnym przemianom, niekiedy daleko idącym, głównie gdy chodzi o rolę elementu spekulatywnego i objawionego w jej budowie, oraz ich wzajemny stosunek i proporcję. Jako nauka dotycząca ludzkiego postępowania, a więc zawierająca w swych wynikach oceny i normy, ulegała też przemianom $\mathrm{w}$ zależności od celu, jaki $\mathrm{w}$ badaniach teologiczno-moralnych stawiano. Przybierała więc charakter niekiedy bardziej spekulatywny, niekiedy zaś bardziej - lub prawie całkowicie - praktyczny i pastoralny ${ }^{6}$.

Pierwotna zatem integracja teologii moralnej, jakkolwiek dokonana niejednolicie i z różnym rozłożeniem akcentów $\mathrm{w}$ jej strukturze, dała w wyniku dyscyplinę dość zwartą, jasno określoną co do jej przedmiotu i zasadniczego aspektu, w jakim ten przedmiot ma być ujmowany. Według koncepcji, która w tradycji teologicznej znalazła największe uznanie i najszersze rozpowszechnienie, teologia moralna ma za przedmiot ludzkie działanie w aspekcie jego skierowania do osiągnięcia określonego celu, mianowicie celu będącego spełnieniem najgłębszych, ostatecznych dążeń natury ludzkiej oraz spełnieniem ostatecznego przeznaczenia człowieka w świetle Objawienia (cel ostateczny w aspekcie naturalnym i nadprzyrodzonym) ${ }^{7}$.

5 Pod tym względem teologia moralna nie jest odosobniona. Podobny postulat został wysunięty w stosunku do teologii dogmatycznej, a dokładniej w stosunku do teologii jako takiej. Postuluje się ujęcie materiału teologicznego w sposób bardziej określony, aniżeli w klasycznej koncepcji teologii jako nauki o Bogu (Deus sub ratione Deitatis) i o przejawach Jego działania w świecie stworzonym (omnia sub ratione Dei). Aspektem wysuwanym na pierwsze miejsce jest związek poszczególnych zagadnień teologicznych z najdonioślejszym dla człowieka tematem Objawienia, jakim jest Tajemnica Zbawienia. W zespole nauk związanych $z$ teologią został także wysunięty postulat integracji w stosunku do apologetyki, która ma ujmować swój przedmiot w aspekcie aksjologicznym jako całościowym, zespalającym dotychczasowe dwa punkty widzenia oddzielne, a zarazem nieodzowne właściwe apologetyce intelektualistycznej i woluntarystycznej, związane z wykrytym wieloaspektowym charakterem procesu dochodzenia do wiary (Laberthonnière, Poulpiquet, Kwiatkowski). Por. Ks. W. Kwiatkowski, Apologetyka totalna. I. Przedmiot $i$ metody apologetyki nowoczesnej, Warszawa, ${ }^{3} 1961$.

6 Tę rozpiętość wykazuje się najczęsciej zestawiając dwie najwybitniejsze postacie w dziejach teologii moralnej - św. Tomasza z Akwinu i $\mathbf{s w}$. Alfonsa Liguori. Obydwaj istotnie utrwalili niejako dwa style uprawiania tej dyscypliny teologicznej. Jednak drugi $\mathrm{z}$ nich doktrynalnie zależny był od pierwszego. Dopiero współcześnie wysunięte zostały propozycje radykalnego przekształcenia teologii moralnej w kierunku praktycznym i pastoralnym, kerygmatycznym (Sailer, Hirscher, Tillman, Häring).

7 Por. J. Gründel, Moraltheologie, w: E. Neuhäusler und E. Gössmann, Was ist Theologie?, München, 1966, s. 228; J. Santeler, Der Endzweck des Menschen nach Thomas von Aquin. Eine kritischweiterfïhrende Studie, „Zeitschr. f. kath. Theologie", 87 (1965) 1-60. 
W związku jednakże z wysiłkami zmierzającymi do podniesienia poziomu teologii moralnej po okresie jej stagnacji i pewnej dekadencji w zakresie zwłaszcza dydaktyki, zwrócono uwagę na zagadnienie jedności tej nauki, a zarazem jej adekwatności do tej treści, która powinna stanowić jej przedmiot rzeczywisty. $\mathrm{Na}$ tym tle, poczynając od pierwszych dziesiątków lat wieku XIX coraz częściej i z coraz to nowych stanowisk wskazywano na konieczność przekształcenia teologii moralnej jako nauki $\mathrm{w}$ ten sposób, by $\mathrm{z}$ jednej strony dawała $\mathrm{w}$ pełni naukowe uzasadnienie norm ludzkiego postępowania, a z drugiej strony oddawała w pełni całą specyfikę moralnej doktryny chrześcijańskiej.

Spełnienie tego postulatu w jego pierwszej części było wiązane przez przeważającą część teologów, a następnie także przez kompetentne organy Kościoła, $z$ nawrotem do koncepcji i metody uprawiania teologii moralnej, jakie pozostawiła tradycja teologiczna okresu scholastyki ${ }^{8}$. Spełnienie zaś tego postulatu w jego drugiej części wielu teologów widziało nie w nawrocie do tradycji scholastycznej, akcentującej ich zdaniem nadmiernie element spekulatywny i racjonalny $w$ teologii, lecz w nawrocie do koncepcji moralności autentycznie chrześcijańskiej, mającej swoje elementarne przedstawienie i swoiste uzasadnienie w Piśmie Swiętym. Ich zdaniem teologia moralna powinna być zrekonstruowana nie według modelu właściwego jakiejkolwiek etyce naturalnej, lecz według modelu zupełnie swoistego, danego wraz z przekazem treści Objawienia ${ }^{9}$.

Rezultatem podejmowanych wysiłków i wysuwanych postulatów od wieku XIX do chwili obecnej, jest szereg prób reintegracji teologii moralnej, zmierzających do nadania jej właściwej jedności wewnętrznej przy zachowaniu całej specyfiki dyrektyw moralnych biblijnych. Ocena tych prób i poszukiwanie rozwiązania w pełni zadawalającego stanowią w chwili obecnej najbardziej aktualne zadanie w zakresie podstawowych zagadnień teologii moralnej. Aktualność tego zadania zwiększa się tym bardziej w okresie dostosowywania całości teologii do wskazań doktrynalnych Soboru Watykańskiego II, że w odniesieniu do koncepcji i metod uprawiania teologii moralnej Sobór w swych dokumentach podał szereg dyrektyw wytyczających zarówno zawartość treściową jak

8 Do odnowy scholastyki przyczyniły się badania historyczne i liczne wznowienia tekstów, podjęte zwłaszcza w drugiej połowie XIX wieku (Perrone, Kleutgen, Taparelli, Liberatore). Twórczość wybitnych teologów (Franzelin, Scheeben), a przede wszystkim zalecenia Leona XIII przynoszą odrodzenie filozofii chrześcijańskiej i rozwój nowej scholastyki, która staje się coraz bardziej tomistyczna. Ta orientacja staje się też przeważającą i na dłuższy czas prawie wyłączną także $\mathrm{w}$ teologii moralnej.

9 Taki program łączył się u niektórych autorów z nastawieniem antyracjonalistycznym (Sailer), lub antyscholastycznym (Hirscher). U innych uwidacznia się dążenie do nadania teologii moralnej charakteru bardziej pastoralnego (Jocham, Fuchs), lub ascetyczno-pastoralnego (Linsenmann). 
i formę przedstawienia autentycznie chrześcijańskiej doktryny moralnej ${ }^{10}$.

Celem, jaki został obrany w niniejszych rozważaniach, jest rozpatrzenie ogólnych wymagań i warunków, jakie muszą być spelnione, aby możliwe było przeprowadzenie integracji teologii moralnej, niezależnie od szczegółowego punktu widzenia, który może być obrany jako zasadniczy lub centralny w świetle Objawienia. Podejmowane ostatnio bardzo często zagadnienie idei centralnej i podstawowej w moralnej nauce Starego lub Nowego Testamentu stanowi problem o doniosłym znaczeniu dla budowy teologii moralnej ${ }^{11}$. Jest to jednak problem $w$ pewnym sensie wtórny i bardziej szczegółowy. Ustalenie miejsca i roli treści objawionych w teologii moralnej staje się możliwe dzięki refleksji o szerszym zasięgu, obejmującym możliwie wyczerpująco wszystkie składniki konieczne takiej dyscypliny, jaką jest etyka teologiczna, etyka spełniająca właściwe sobie zadanie $\mathrm{w}$ ten sposób, że nie przestaje być częścią teologii ${ }^{12}$.

\section{II}

Podjęcie rozważań nad charakterem teologii moralnej jako etyki teologicznej wymaga przede wszystkim sprecyzowania sensu wiązanego z pojęciem etyki naukowej.

„Naukowość” etyki - to określenie uzależnione oczywiście w swej treści od koncepcji nauki. Ten ostatni termin stanowi nazwę analogiczną, oznaczającą zarówno czynności poznawcze dokonywane „w sposób naukowy" ${ }^{13}$, jak też wytwór tych czynności, czyli "naukę" w sensie wiedzy o określonych przedmiotach. Wiedzę rozumie się jako zespół sądów lub zdań wyrażających określone twierdzenia o faktach, stanach, rzeczach, zdarzeniach.

Zdania, w których zawiera się wiedza naukowa, muszą spełniać określone wymagania. Wśród nich wymaganie zasadności, czyli legitymowania się wystarczającymi racjami, dla których mogą one być uznane za prawdziwe ${ }^{14}$. W przypadku wiedzy etycznej to wymaganie posiada

10 Zwłaszcza w Dekr. o formacji kapłanów n. 16. Por. J. Fuchs SJ, Moral und Moraltheologie nach dem Konzil, Wien, 1967; B. Häring, Moralverkündigung nach dem Konzil (Theol. Brennpunkte, Bd. 3/4), Bergen-Enkheim, 1966.

11 Por. Ks. L. Stachowiak, Biblijne ujęcie węzłowych zagadnień moralnych, „Studia Theol. Varsaviensia”, 6 (1968), nr 1, ss. 1-28.

12 Por. Ks. B. Inlender, Dwie koncepcje stosunku etyki filozoficznej do teologii moralnej, „Studia Theol. Varsaviensia”, 6 (1968), nr 1, ss. 71-86; Ks. St. Smoleński, Teologia moralna wobec potrzeb świata wspólczesnego, „Coll. Theol.”, 38 (1968), fasc. I, ss. $19-29$.

${ }_{13}$ Taki sposób definiowania nazwy ,nauka” zachowuje swoją poprawnośc dzięki uprzedniemu sprecyzowaniu, jakie rygory powinny być spełnione. aby przeprowadzane badania mogły być uznane za naukowe.

14 Wymaganie intersubiektywnej sprawdzalności zdań naukowych można tu pominąc jako w pewnym sensie oczywiste. "Uzasadnienie" zdań implikuje to wy- 
szczególnie doniosłe znaczenie ze względu na praktyczny charakter nauki, jaką jest etyka (w każdej jej postaci). W klasyfikacji nauk przyjmującej podział nauk na teoretyczne, mówiące „o tym, co jest” i praktyczne, mówiące „o tym, co być powinno" - etyka zaliczana jest do praktycznych na tej zasadzie, że jej zdania określają to, „,co być powinno” w działaniu ludzkim ${ }^{15}$. Ten właśnie charakter jej zdań stwarza znany problem zasadności twierdzeń i takiej lub innej powinności w oparciu o twierdzenia, mogące dla nich stanowić logiczne racje. Wśród twierdzeń takich bowiem występują $w$ etyce $z$ reguły także twierdzenia (zdania) mówiące i o tym, co jest. Pomijając zagadnienie rzeczywistego sensu tego problemu i jego rozwiązanie, należy wziąć pod uwagę fakt występowania w uzasadnieniach etycznych zdań o treści nie normatywnej, lecz opisowej, dotyczącej rzeczywistości ${ }^{16}$.

Fakt ten nie przekreśla naukowego charakteru wiedzy etycznej, skoro samo występowanie tego rodzaju uzasadnień zostaje uznane za prawomocne w naukach praktycznych. Zdania opisowe, mówiące o rzeczywistości nie tylko nie usuwaja naukowego charakteru zbioru, jaki stanowią zdania - normy, lecz także same, wraz z normami, składają się na zbiory zdań tworzących określone nauki praktyczne ${ }^{17}$.

W związku z tym należy przyjąć, że etyka naukowa w znaczeniu ścisłym jest to zbiór ocen i norm określających z właściwego etyce punktu widzenia postępowanie człowieka. W znaczeniu zaś szerszym, będącym $w$ powszechnym użyciu, jest to zbiór ocen i norm oraz tych wszystkich zdań opisowych, mówiących o rzeczywistości, które stanowią uzasadnienie, względnie podłoże formułowania ocen i norm, czyli uzasadnienie $\mathrm{w}$ swoistym, właściwym etyce sensie. To szersze rozumienie nazwy „etyka” znajduje naturalne uzasadnienie w fakcie, że istnieją istotne różnice pomiędzy historycznie danymi systemami etycznymi. Różnice te są wynikiem różnorodności twierdzeń wyjściowych o człowieku i jego działaniu. Konkretne „etyki” są charakteryzowane nie tylko treścią swych tez wynikowych, to znaczy ocen i norm, lecz także

maganie, ponieważ jego spełnienie jest koniecznym warunkiem uzasadnienia zdań w sensie obiektywnym.

15 Wypowiedziom etycznym przysługuje zatem charakter zdań, zarówno wtedy, gdy wyrażają one oceny, jak i wtedy, gdy mają treść normatywną.

16 Na temat krytyki uzasadniania zdań normatywnych zdaniami orzekającymi, podniesionej przez D. Hume’a i kontynuowanej współcześnie przez przedstawicieli neopozytywizmu (m. in. Stevenson, von Wright, Popper, Hare) por. ks. T. Styczeń SDS, W sprawie przejścia od zdań orzekających do powinnościowych, „Roczn. Filoz.”, 14 (1966), z. 2, ss. 65-80; Problem poznania prawa naturalnego, w: "Studia Theol. Varsaviensia", 6 (1968), nr 1, ss. 121-170.

17 Por. J. Kalinowski, Teoria poznania praktycznego, Lublin, 1960. Charakter zdań nienormatywnych, wchodzących w skład zbiorów, jakie stanowią nauki praktyczne, bywa określany niejednakowo. Niekiedy nie uznaje się ich charakteru teoretycznego. Por. H. Stonert, Charakterystyka twierdzen nauk praktycznych $w$ aspekcie metodologicznym, „Prakseologia”, 28 (1967) 21-55. 
treścią tez bazowych, to znaczy twierdzeń wyrażających koncepcję czlowieka i wiedzę o człowieku ${ }^{18}$.

Zatem, do zbioru zdań tworzących etykę - w jej znaczeniu szerszym, o którym tu mowa - wchodzą również zdania należące do zbiorów zdań tworzących inne nauki. Są to najczęściej zdania o treści ogólnej, ujmujące syntetycznie, czyli w formie wniosków uogólnionych, wiedzę o człowieku, o jego warunkach bytowania, w ogóle wiedzę, mającą znaczenie dla dokonywanych przez czlowieka wyborów w sprawach dla jego egzystencji podstawowych. W ten sposób etyka czerpie z zasobu wyników innych nauk ${ }^{19}$, który ulega nieustannemu poszerzaniu, a niekiedy także modyfikacji ze względu na postęp tych nauk i zastępowanie jednych teorii innymi, lub ze względu na uzyskiwanie wyników coraz bardziej poprawnych i ścisłych.

W tej kategorii zdań szczególną rolę pełnią zdania o treści najbardziej ogólnej, ponadempirycznej, abstrakcyjnej — filozoficznej, dotyczącej człowieka i jego postępowania. Tworzą one antropologię metafizyczną, określającą naturę człowieka i jego stosunek do świata (oraz do Boga) w sposób najbardziej podstawowy, to znaczy w kategoriach metafizycznych. Obecność takich właśnie zdań w zbiorze, jakim jest etyka, staje się źródłem wiedzy etycznej w ściślejszym znaczeniu tego określenia, wiedzy o wartości czynów (oceny) i o właściwych normach postępowania ludzkiego (normy moralne), ponieważ tylko wiedza o człowieku jako takim może się stać źródłem ocen i norm o znaczeniu ogólnym, ważnych dla każdego człowieka, przynajmniej, gdy chodzi o ocenę i normowanie podstawowe, nie odnoszące się do czynów konkretnych, jednostkowych ${ }^{20}$.

Jeżeli zatem wyjść w analizie pojęcia etyki naukowej ze stanowiska, że etyka jest wiedzą o właściwym postępowaniu, czyli wiedzą normatywną przede wszystkim lub wyłącznie, wówczas należy uznać w jej budowie dwie niejako warstwy. W jednej z nich etyka obejmuje zdania zawierające wiedzę o człowieku faktyczna, którą tworzą zdania wyni-

18 Należałoby właściwie mówić o istnieniu tylko jednej „etyki”, mianowicie etyki prawdziwej, to znaczy operującej jedynym prawdziwym kryterium oceny moralnej i jedynym prawdziwym uzasadnieniem powinności etycznej. Wskazanie takiej etyki, czyli przedstawienie koncepcji etyki naukowej, którą się uznało za prawdziwą, powinno poprzedzać metodologię etyki. Jednakże refleksja metodologiczna jest w rzeczywistości uprawiana względem historycznie danych systemów etycznych i ma charakter przede wszystkim opisowy, sprawozdawczy: analizuje sysiemy zaliczane do dziedziny etyki. Por. Ks. St. Kamiński, O różnych rodzajach wiedzy o moralności, „Studia Theol. Varsaviensia”, 6 (1968), fasc. 1, ss. 193-204.

${ }_{19} \mathrm{~W}$ tym też sensie $\mathrm{w}$ terminologii tradycyjnej zależność jednej dziedziny naukowej od innej była określana jako "subalternatio".

20 Stanowisko określane jako sytuacjonizm kwestionuje właśnie możliwość wiedzy ogólnej o człowieku, a stąd istnienie ogólnych i niezmiennych norm postępowania. Konsekwentnie uznaje jedynie istnienie wiedzy etycznej w odniesieniu do każdorazowo danej, konkretnej sytuacji, której moralne znaczenie i związane z nią wymagania są poznawane jednostkowym, konkretnym aktem oceny moralnej. 
kowe empirycznych nauk pomocniczych etyki oraz zdania wynikowe antropologii metafizycznej. W drugiej zaś warstwie etyka obejmuje zdania zawierające oceny i normy ludzkiego postępowania. Wiedza zawarta w tej drugiej warstwie wypływa z poprzedniej na zasadzie swoistego, etycznego „wynikania”, jest osiągana dzięki przyjęciu swoistej postawy myślowej, właściwej myśleniu etycznemu ${ }^{21}$.

Jeżeli jednak w analizie pojęcia etyki wziąć pod uwagę modele systemów etycznych, w których punktem wyjścia zasadniczym lub równorzędnym są tak zwane fakty moralne, wówczas należy uznać w budowie etyki warstwę trzecią, obejmującą zdania służące wyjaśnieniu samej moralności jako faktu danego obiektywnie w postaci ocen i norm uznanych, oraz subiektywnie w postaci jawiącej się podmiotowo wartości, powinności czy odpowiedzialności.

Tego rodzaju wyjaśnienie przybiera z konieczności charakter filozoficzny, skoro pytania, jakie rodzi zetknięcie się z rzeczywistością moralną, domagają się odpowiedzi o charakterze ostatecznym, to jest takich, które nie wskazują już na potrzebę i możliwość odpowiedzi jeszcze bardziej ogólnych i podstawowych ${ }^{22}$. Jest to znamienna cecha pytań dla człowieka najistotniejszych. Skąd kategoryczny charakter naciskającej powinności, skąd absolutny charakter jawiącej się wartości etycznej? Filozoficzny sens takiego wyjaśnienia polega na odwołaniu się do ostatecznych racji i przesłanek koniecznych dla zrozumienia rzeczywistości. Są nimi dane dotyczące bytu jako takiego.

Ta warstwa w budowie etyki ma charakter wyjaśniającej teorii metafizycznej i w swej treści w dużym stopniu pokrywa się z wiedzą określoną poprzednio jako antropologia metafizyczna. Obejmuje ona jednak ponadto zdania zawierające pojęcia dla niej swoiste jak ,dobro etyczne”, „cel”, „wartość” itd. Pełni ona funkcję podwójną; z jednej strony wyjaśniającą fenomen moralności i w tym aspekcie stanowi ,filozofię moralności", z drugiej zaś motywującą szczegółowe oceny i normy moralne. W tym aspekcie stanowi ,filozofię moralną”, lub według innych ujęć, część filozofii moralnej rozumianej jako całokształt twierdzeń etycznych, ogólnych i szczegółowych.

21 Swoistość procesu myślowego, w którym dochodzimy do poznania norm etycznych, może być wykazana jedynie w odniesieniu do systemów, które nadaja „powinności" etycznej inny sens, aniżeli tylko prostego wynikania na zasadzie konieczności użycia środka do zamierzonego celu nieobowiązującego, lecz tylko pożądanego (maksymalizacja szczęścia, korzyść itd.).

22 W ramach każdego systemu etycznego można znaleźć jakieś elementy wyjaśnienia rzeczywistości moralnej. Niekiedy jednak są one podane tylko marginesowo, ze względu na nieuniknione powiązanie pomiędzy koncepcją wartości etycznej i teorią poznania wartości etycznej. W systemach nacechowanych empiryzmem i pozytywizmem wyjaśnianie rzeczywistości moralnej zatrzymuje się niejako na powierzchni zjawisk i nie daje odpowiedzi na pytanie o źródło i ostateczną podstawę obowiązku moralnego, lecz pytanie to uchyla traktując treść przeżyć moral- 
Rozważania zatem dotyczące teologii moralnej (jako etyki teologicznej) i warunków jej integracji wymagają uwzględnienia zróżnicowanych aspektów ujawniających się w analizie etyki. Wymagają one jednak uwzględnienia także doniosłej różnicy zachodzącej w samej treści formułowanych $\mathrm{w}$ etyce ocen i norm. Różnica staje się widoczna przy wniknięciu $\mathrm{w}$ treść, jaką wiąże się $\mathrm{z}$ wyrażeniami typowymi dla języka etycznego w różnych systemach etycznych a niekiedy także w obrębie jednego i tego samego zespołu zdań związanych $\mathrm{z}$ określonym systemem etycznym. Polega ona na dwojakim rozumieniu niektórych wyrażeń języka etycznego takich jak ,,powinien”, ,dobry”, ,stosowny” itp. W jednym wypadku spotyka się ich użycie i rozumienie w sensie, który jest dostępny $\mathrm{w}$ bezpośrednim doznaniu kontaktu $\mathrm{z}$ wartością etyczną, zwłaszcza gdy ujawnia się jej aspekt wiążący w sposób bezwzględny, nie zaś fakultatywny. W innym zaś wypadku spotyka się ich rozumienie w sensie, który może być uchwycony w ścisłym związku z samym systemem etycznym, w którego kontekście wyrażenia takie są użyte.

W tym drugim przypadku wyrażenia przytoczone, a także szereg innych, są niezależne od tej treści, jaką ujawnia w podmiotowym aspekcie samo przeżycie moralne, na przykład rozpoznanie wartości etycznej wiążącej. W kontekście systemu hedonistycznego zatem wyrażenie „,powinien" dotyczy konieczności określonego postępowania ze względu na to, że takie postępowanie jest warunkiem osiągnięcia określonej przyjemności. Wyrażenie to natomiast nie dotyczy istnienia „konieczności” lub ,powinności" związanej z określonym postępowaniem i rozpoznawanej w związku z uświadomioną treścią tego postępowania. Nie jest to więc rozumienie powinności, jakie wytwarza niejako wgląd w moralną stronę postępowania ludzkiego lecz rozumienie płynące z rozważenia związków przyczynowych pomiędzy zamierzonym celem i określonym działaniem ${ }^{23}$.

Ta sama różnica uwidacznia się w języku etycznym przy porównaniu treści wiązanej ze zdaniami dyrektywnymi występującymi w różnych systemach etycznych lub nawet $w$ obrębie zespołu zdań wiązanych $\mathrm{z}$ jednym i tym samym systemem etycznym. Zdania te w pewnych wypadkach wyrażają istnienie konieczności określonego postępowania czyli są normami w ścisłym znaczeniu. W innych wypadkach zdania te wyrażają „konieczność” określonego postępowania dającą się uchwycić jedynie drogą bezpośredniego wglądu w treść czynu, charakter osób w tym czynie zaangażowanych i ich wzajemną relację. Ma to miejsce na przy-

nych jako projekcję świadomościową czynników biologicznych, psychologicznych lub społecznych.

${ }_{23}$ Nie jest to zatem powinność bezwzględna, lecz właśnie uwarunkowana i oznacza jedynie zachodzący związek przyczynowy pomiędzy przyczyną i skutkiem, który musi być wzięty pod uwagę, jeżeli zamierzony cel ma być osiągnięty. 
kład w wypadku dyrektyw mówiących o wymaganiach, jakie stawia autentyczna międzyosobowa miłość. Takie zdania ze swej treści są dyrektywami, to znaczy ,zalecają" określone postępowanie, w tym wypadku $\mathrm{w}$ imię pełnego czy doskonalszego spełnienia tych wymagań, jakie potrafią rozpoznać miłujący w stosunku do osób miłowanych. Stają się one normami w sensie subiektywnym, dla samych miłujących, gdy ich treść jest przeżywana wraz z poczuciem bezwarunkowej konieczności określonego postępowania lub wewnętrznego nastawienia, „ze względu na osobę miłowaną" ${ }^{24}$.

Normami w znaczeniu obiektywnym, intersubiektywnie ważnym, stają się natomiast dopiero w wyniku przemiany ich treści w ten sposób, że $\mathrm{w}$ rezultacie refleksji etycznej nad osobą ludzką w ogólności, mówią one o konieczności określonego postępowania wypływającej z charakteru osoby jako osoby. Wówczas występujące w takich zdaniach - normach terminy powinnościowe dotycza w swym znaczeniu prawidłowości określonego postępowania, to jest jego zgodności z istniejącym stanem rzeczy, czyli z sytuacją etyczną osoby. Otwarty pozostaje problem, czy każda postać norm danych $\mathrm{w}$ bezpośrednim doznaniu może być weryfikowana przez okazanie jej wynikania z norm obielktywnych najbardziej podstawowych, lub z samych wyjściowych dla etyki twierdzeń o rzeczywistości.

Integracja teologii moralnej, jako swoistej formy etyki naukowej, wymaga - tak jak w przypadku każdej innej nauki — uwzględnienia dwóch aspektów procesu integracyjnego. Jednym $\mathrm{z}$ nich jest aspekt treściowy, lub inaczej zakresowy, związany z samym materiałem, który wchodzi w skład wiedzy zawartej w określonej nauce. Drugim zaś jest aspekt formalny, związany $\mathrm{z}$ kątem widzenia, pod jakim jest ujmowany przedmiot nauki.

Wskazanie całego koniecznego zakresu informacji, jaki na terenie określonej nauki musi być wzięty pod uwagę celem nadania jej jedności, stanowi niejako pierwszą fazẹ procesu integracji i może być określone jako integracja zakresowa. Wskazanie natomiast aspektu, który może i powinien być uznany za nadrzędny w określonej nauce na danym etapie jej rozwoju i dzięki temu może jej nadać wewnętrzną jedność, stanowi fazę drugą i może być określone jako wewnętrzna integracja nauki ${ }^{25}$.

24 Ma to miejsce zwłaszcza, jak się zdaje, gdy chodzi o subiektywnie rozpoznawaną konieczność zamanifestowania miłości przez całkowity dar ze siebie. Sprawie intuicyjnego sensu języka etycznego poświęcamy oddzielne rozważania na innym miejscu.

${ }_{25}$ Próba objęcia jedną nauką całości problematyki wiązanej dotychczas z pojęciem „moralności" może prowadzić przy jednostronnej postawie teoriopoznawczej do odrzucenia $\mathrm{w}$ ogóle możliwości istnienia jakiegoś aspektu integrującego tę dzie- 
Integracja zakresowa w przypadku etyki - także etyki teologicznej - stwarza pewną szczególną trudność, związaną z koniecznością objęcia $\mathrm{w}$ tej nauce bardzo szerokiego i wciąż rosnącego zakresu informacji dotyczących człowieka, jako podmiotu a zarazem przedmiotu działania etycznego. Teologia moralna jest etyką w sensie ścisłym dzięki temu, że zawiera oceny i normy ludzkiego postępowania. Staje się natomiast etyką naukową dzięki temu, że zawiera uzasadnienie tych ocen i norm ${ }^{26}$.

Uzasadnienie to, jak w ogóle w etyce, tworzą informacje o człowieku i jego sytuacji w świecie, prowadzące do ocen i norm. Oceny przy tym i normy najogólniejsze znajdują uzasadnienie w najbardziej ogólnych, podstawowych informacjach o człowieku, czyli w zakresie, który został poprzednio określony jako ,antropologia”. Oceny natomiast i normy szczegółowe, dotyczące bardziej specjalnych kategorii czynów ludzkich, znajdują uzasadnienie $z$ jednej strony $w$ tych ogólnych ocenach i normach, z drugiej zaś w informacjach o konkretnych warunkach określonego działania ludzkiego, to znaczy o treści, skutkach lub warunkach tego działania. Ta kategoria informacji szczegółowych pozwala formułować oceny i normy dla poszczególnych, najbardziej konkretnych rodzajów działalności ludzkiej, włącznie z etyką zawodu, kazuistyką specjalną itd.

Uzasadnienie ocen i norm jednak, zarówno w sensie ogólnym jak i szczegółowym wymaga informacji dotyczących warunków spełniania samego czynu, warunków powstania odpowiedzialności itp. Informacje te zawarte są częściowo wśród podstawowych informacji ,,antropologii", częściowo zaś pochodzą z nauk opisujących i wyjaśniających ludzkie działanie (psychologia, socjologia i pokrewne) ${ }^{27}$.

dzine, a także możliwości istnienia jednej, prawidłowo zbudowanej dyscypliny etycznej. Właśnie na tej zasadzie, że „moralność” przy dokładniejszej analizie okazuje się pojęciem niespójnym, II. Ossowska uznała jedynie możliwość zbudowania kilku odrębnych dyscyplin etycznych, odrzuciła natomiast możliwość budowy etyki jako jednej systematycznej nauki. Por. Podstawy nauki o moralności, Warszawa, 1947, s. 340. Stanowisko takie może być uznane za słuszne jedynie wtedy, gdy się przyjmuje, że „moralność” jest istotnie nazwą niespójną, to znaczy mającą heterogeniczne kiasy desygnatów i wobec tego jest nazwą analitycznie niedefiniowalną z tym jednak, że heterogeniczność rozumie się jako całkowitą różność. Tylko wtedy bowiem taka nazwa łączy zupełnie różne gatunki przedmiotów. Jeśli jednak dostrzega się, że w tym wypadku zachodzi jedynie częściowa heterogeniczność, to wówczas wolno przyjąć, że „moralność” nie łączy przypadkowo jako nazwa przedmiotów całkowicie różnych, lecz że łączy różne klasy desygnatów poprzez znaczenia analogiczne, a więc pod pewnym przynajmniej względem podobne. Por. Ks. St. Kamiński, Gergonne'a teoria definicji, Lublin, 1958, ss. $12 \mathrm{nn}$.

26 Uzasadnienie w teologii oznacza nie tylko wykazanie, że określone zdania zawierają się lub znajdują logiczne oparcie w źródłach Objawienia, lecz także oznacza, że twierdzenia rozwijające lub wyjaśniające tezy objawione, są oparte na prawdziwych twierdzeniach rozumowych i zostały z nich prawidłowo pod względem logicznym wyprowadzone.

27 Informacje te różnią się oczywiście stopniem pewności. Im bardziej mają 
Teologia moralna zatem staje się etyką $\mathrm{w}$ znaczeniu szerszym dzięki temu, że włącza do właściwego sobie zbioru zdań również takie, które zawierają informacje z zakresu filozofii i nauk szczegółowych, niezbędne w jakiejkolwiek etyce (w jej znaczeniu szerszym). Szczególną, wspomnianą wyżej trudność stanowi wybór tego rodzaju informacji, zwłaszcza w zakresie nauk szczegółowych. Ich zasięg może być prawidłowo ustalony dopiero $\mathrm{w}$ świetle nadrzędnego aspektu etyki, wyłonionego w związku z jej integracją wewnętrzną. W każdym zaś wypadku zasób tych informacji musi wzrastać wraz z postępem wiedzy o człowieku.

Koncepcja teologii moralnej jednak, jako etyki teologicznej, zakłada konieczność, a zarazem możliwość, uzasadnień w oparciu o dane teologiczne w ścisłym znaczeniu tego słowa, to znaczy o dane objawione. W odniesieniu do ocen i norm moralnych tego rodzaju uzasadnienie ma dwojaką postać.

Uzasadnienie to, po pierwsze, przybiera formę nakazów lub zakazów skierowanych do określonych adresatów, bądź też do ludzi jako takich. Zawierające je zdania mają formę rozkaźników, reguł prawnych lub innych wypowiedzi równoważnych, albo też formę ocen prowadzących mniej lub więcej pośrednio do wniosków dyrektywnych ${ }^{28}$.

Po drugie uzasadnienie to przybiera formę informacji o człowieku, zwłaszcza o jego relacji do świata i Boga. Zawierające je zdania nie mają w tym wypadku formy rozkaźników lub ocen. Stają się jednak również źródłem wiedzy etycznej o charakterze dyrektywnym. Treść tej wiedzy zostaje ujawniona dwoma sposobami: drogą swoistego, ,etycznego" wnioskowania $\mathrm{z}$ danych ogólnych o człowieku zawartych w przekazie objawionym oraz drogą odwołania się do ocen i postaw, powstających w zetknięciu się człowieka z objawioną mu prawdą o wielkości, świętości, a zwłaszcza miłości Boga.

charakter ogólny, abstrakcyjny, tym większą mają pewność i powszechność zastosowania. Im bardziej zaś są szczegółowe i empiryczne w swej treści, tym bardziej nabierają charakteru twierdzeń tylko prawdopodobnych i odniesionych do ograniczonej ilości przypadków. Należą bowiem do zakresu wiedzy rzeczowej (realnej) i częściowo ogólnej, ale tylko prawdopodobnej.

${ }_{28}$ Dokonanie pełnego zestawienia tego rodzaju nakazów i ocen jest obecnie zadaniem egzegezy biblijnej i teologii biblijnej. Konieczne też jest ich usystematyzowanie $\mathrm{w}$ miarę jak pozwala na to sama treść przekazu objawionego. Pilnym zadaniem jest również odróżnienie w treści moralnej Objawienia, wyrażonej $\mathrm{w}$ tekstach biblijnych, norm powszechnych i indywidualnych, stałych i czasowych, bezwzględnych i uwarunkowanych historycznie. Najpełniejsze zestawienie wskazań moralnych Nowego Testamentu wraz z wnikliwą analizą podali dotąd R. Schnackenburg, Die sittliche Botschaft des Neuen Testamentes, München, 21962 oraz C. Spicq, Théologie morale du Nouveau Testament, Paris, 1965. Rola teologii biblijnej jako podstawy teologii dogmatycznej była dotychczas bardziej akcentowana, aniżeli w odniesieniu do teologii moralnej. IIetodologicznym problemem pozostaje stosunek teologii biblijnej (także moralnej) do egzegezy $z$ jednej strony, a do teologii spekulatywnej z drugiej. Por. Ks. W. Granat, Nauki teologiczne, w: Dogmatyka katolicka, Tom wstępny, Lublin, 1965, ss. 7-50; Ks. K. Romaniuk, Pismo św. a teologia dogmatyczna, w tejże pr. zbior., ss. 115-130. 
W treści Objawienia w wielu wypadkach intencja normowania ludzkiego postępowania nie jest $\mathrm{w}$ ogóle ujawniona, a uznanie konieczności określonego nastawienia i działania wypływa wprost $\mathrm{z}$ rozeznania treści i znaczenia określonych faktów, będących objawieniem się Bóstwa. Ta droga ujawnienia treści etycznej Objawienia w wielu wypadkach została wskazana otwarcie $\mathrm{w}$ formie odwołania się do oczywistości wynikania określonych postaw wewnętrznych i działań z poznania faktów objawionych ${ }^{29}$.

Uzasadnienie etyczne natomiast, przybierające formę nakazów względnie zakazów, ma charakter odmienny i zawiera jakby dwa poziomy. $\mathrm{Na}$ pierwszym z nich uzasadnienie to ma charakter jurydyczny - jest „uzasadnieniem" normy prawnej przez odwołanie się do woli ustawodawczej zwierzchnika. Na drugim zaś uzasadnienie to ma charakter etyczny, jest bowiem ujawnieniem poprawności lub wadliwości etycznej określonych postaw wewnętrznych i działań, albo też jest ujawnieniem skonkretyzowanej woli zwierzchnika i odwołaniem się do momentu etycznego, jakim jest uznanie zarówno jego kompetencji prawodawczej, jak też wartości etycznej posỉuszeństwa.

Analiza zdań dyrektywnych występujących w przekazie objawionym wykazuje istnienie $\mathrm{w}$ nim zarówno norm we właściwym tego słowa znaczeniu, jak też zdań oceniających, kwalifikujących określone sposoby działania $z$ punktu widzenia ich mniejszej lub większej doskonałości. Do tej drugiej kategorii należą zdania będące ocenami oraz zdania wyrażające jednocześnie ocenę i swego rodzaju wezwanie do wyboru i realizacji działania o wyższej kwalifikacji w skali ocen przyjętych ${ }^{\mathbf{3 0}}$.

W związku z tym teologia moralna jako etyka (w znaczeniu ścisłym) ujawnia z punktu widzenia formy i treści zdań dyrektywnych dwa poziomy i dwa zakresy: zakres dyrektyw wiążących bezwzględnie, w oparciu o oceny „dobry” — „zły”, oraz zakres dyrektyw wiążących względnie, w oparciu o oceny ,doskonalszy” — „mniej doskonały”.

\section{IV}

Przeprowadzone tu zestawienie różnego rodzaju zdań, wchodzących do zbioru jaki tworzy teologię moralną, pozwala na sporządzenie swego rodzaju inwentarza zdań. Należy do niego włączyć: $1^{\circ}$ - zdania o treści

29 Por. np. Mt 5, 44-45; Łk 6, 31-35; Ef 5, 1-2; Kol 3, 12. Por. A. Grail-J. Schmitt, Grandes lignes de la morale du Nouveau Testament, „Lumière et Vie”, 21 (1955) 3-123; D. Wiederkehr, Die Theologie der Berufung in den Paulusbriefen, Freiburg, 1963; J. Kraus, Vorbildethik und Seinsethik im Neuen Testament, „Freib. Zeitschr. f. Phil. u. Theol.", 13/14 (1966/67), Heft 3, ss. 341-369.

30 Por. np. Mt 19, 21; 'Ek 18, 29; J 15, 9-10; 2 Kor 6, 1. - A. Utz, Wesen und Sinn des christlichen Ethos, München, 1942; E. Neuhäusler, Anspruch und Antwort Gottes, Düsseldorf, 1962. 
opisowej (egzystencjalnej), dotyczące człowieka w aspekcie jego natury metafizycznej, osobowej; $2^{\circ}$ - zdania opisowe, informujące o przejawach i treści zjawiska moralnego; $3^{\circ}$ - zdania, zawierające informacje o czynnikach formujących, ewentualnie deformujących ludzkie rozeznanie wartości moralnej; $4^{\circ}$ - zdania o treści metafizycznej, dotyczące człowieka jako podmiotu działania moralnego, mające aspekt opisowy a zarazem normatywny - wyjaśniające (metafizyczne) zjawisko moralne; $5^{\circ}$ - zdania opisowe, czerpane z zakresu nauk szczegółowych o człowieku, posiadające znaczenie dla konkretyzacji dyrektyw etycznych; $6^{\circ}$ zdania o treści normatywnej ogólnej i szczegółowej; $7^{\circ}$ - zdania o treści dyrektywnej zalecające określone działania w oparciu o bezpośrednie rozpoznanie etycznej „,wzniosłości” lub „doskonałości”; $8^{\circ}$ - zdania o treści teologicznej (objawionej) informujące o człowieku i jego relacji zasadniczej do świata i Boga; $9^{\circ}$ - zdania o treści objawionej zawierające informacje o faktach będących objawieniem się Boga, zwłaszcza w aspekcie Jego stosunku do człowieka (Stworzenie i Zbawienie); $10^{\circ}$ zdania o treści objawionej informujące o elementach zjawiska moralnego (wina, kara, odpowiedzialność, sumienie, nagroda, prawo); $11^{\circ}$ zdania normujące ludzkie działanie $\mathrm{w}$ formie reguł prawnych; $12^{\circ}$ zdania dyrektywne zalecające określone działania przez ich kwalifikację w skali oceny moralnej albo przez odwołanie się do ich „wzniosłości” lub „doskonałości” rozpoznawanej bezpośrednio; $13^{\circ}-$ zdania o treści objawionej, tworzące motywację dla określonych norm i dyrektyw, mającą charakter pozamoralny (korzyść, sankcja), wspóldziałająca $w$ formowaniu postaw etycznych i wypełnianiu norm (elementy wychowania moralnego).

Sporządzenie tego rodzaju inwentarza pozwala w sposób syntetyczny unaocznić cały zakres treści, jaka ma być wzięta pod uwagę $\mathrm{w}$ procesie integracji teologii moralnej i stanowi jej fazę pierwszą. Powstaje z kolei pytanie, jaki aspekt powinien być wskazany jako nadrzędny tak, aby można dokonywać wyboru informacji w ten sposób, by do zbioru, jakim ma być teologia moralna, włączone zostały te i tylko te informacje (a w konsekwencji i zdania), które mogą tworzyć jedną naukę ${ }^{31}$.

Odpowiedź na to pytanie wymaga liczenia się z zasadniczą niejedro-

31 Znalezienie takiego aspektu nie oznacza możności wyliczenia $w$ konsekwencji wszystkich możliwych zđań informujących o człowieku, ani też wyliczenia wszystkich możliwych ocen i norm. Obydwa te zbiory pozostaną zawsze otwarte: pierwszy z nich ze względu na ciągły rozwój wiedzy empirycznej i filozoficznej o człowieku, drugi zaś ze względu na formułowanie coraz bardziej szczegółowych i dostosowanych do sytuacji ocen i norm, zarówno etycznych, jak i teologicznych. Aspekt integrujący $w$ teologii moralnej stanowić będzie kryterium rozstrzygające każdorazowo o włączeniu określonych zdań do zbioru. Tak np. okaże się konieczne włączenie zdań mówiących o relacjach wzajemnych jednostki i grupy, jeżeli teologia moralna miałaby ujmować swój przedmiot w aspekcie „eklezjalnym”, czyli w aspekcie zbawienia jednostek poprzez ustanowioną przez Boga społeczność. 
rodnością treści objętej zdaniami wskazanymi w inwentarzu. Występujące tu zdania rozpadają się przede wszystkim na dwie kategorie: zdania opisowe i zdania dyrektywne. Pierwsze mówią o zachodzących faktach, drugie o powinności lub większej wartościowości związanej z działaniem.

Powiązanie opisu i dyrektyw jest możliwe w oparciu o pojęcie celu i pojęcie powinności. Systemy etyczne operujące pojęciem celu iączyły z nim pojęcie powinności w dwojaki sposób: albo w sensie konieczności realizacji środków dla realizacji tego, co jest powinnością (w znaczeniu konkretnym), czyli dla realizacji celu założonego i zadanego $z$ góry. W pierwszym wypadku system ma postać etyki, lecz nie ma charakteru prawdziwie moralnego (powinnościowego). Wysunięcie aspektu celowościowego, jako nadrzędnego $\mathrm{w}$ teologii moralnej, pozbawiłoby ją oczywiście charakteru autentycznej etyki ${ }^{32}$.

W drugim natomiast wypadku system ma charakter prawdziwie moralny, ponieważ cel jest realizowany ze względu na związaną z nim powinność. Możliwe jest zatem tylko wysunięcie celu jako aspelstu w etyce głównego, ale podporządkowanego powinności, ściśle z nią związanego: realizuję cel określony, ponieważ taka jest moja powinność, a jednocześnie spełniam tę powinność, bo właśnie taki jest mój cel dany mi wraz z moim człowieczeństwem, cel będący powinnością ${ }^{33}$.

Wysunięcie aspelstu celowościowego $\mathrm{w}$ takim powiązaniu $\mathrm{z}$ aspektem powinnościowym w teologii moralnej pozwoliłoby jej zachować charakter autentycznej etyki, lecz pozostawiłoby poza jej nawiasem cały zakres zdań mówiących o działaniu wprawdzie nie leżącym na linii koniecznych środków realizacji celu, lecz pożądanym ze względu na jego „wzniosłość" etyczną, doskonałość moralną itd. i to zarówno z punktu widzenia czysto naturalnego, jak też — by użyć języka teologii — nadprzyrodzonego. Prowadzi to do wniosku, że aspektem nadrzędnym nie może być wzgląd na realizację tak lub inaczej pojętego celu, lecz wzgląd na swoistą wartość moralną, ujawniającą się przy właściwym wglądzie w charakter czynów i postaw wewnętrznych człowieka ${ }^{34}$.

32 System reguł postępowania mających zapewnić np. maksimum przyjemności (hedonizm), jest również określony jako ,system etyczny", a to $\mathrm{z}$ tej racji, że w ogóle coś zaleca lub mówi o pewnej ,konieczności” określonego postępowania. Jednak różni się on zasadniczo od innych systemów, operujących pojęciem powinności nieuwarunkowanej, którą tu przyjmujemy jako nieodzowny sprawdzian moralności i etyki ,autentycznej”. Aspekt natomiast celowościowy (i samo pojęcie celu) jest $\mathrm{z}$ pewnych względów nieodłączne od etyki i tym samym od teologii moralnej. Nie może jednak zajmować pozycji naczelnej w oderwaniu od aspektu powinności nieuwarunkowanej.

${ }_{33}$ Takie powiązanie pojęć celu i powinności charakteryzuje arystotelesowsko-tomistyczną koncepcję i teorię moralności.

${ }_{34}$ "Wartość" wprowadzamy tu w oderwaniu od wszelkich znaczeń związanych z określonymi filozoficznymi teoriami wartości, zwłaszcza wartości moralnej. Chodzi jedynie o „wartościowość" dodatnią lub ujemną, to znaczy o posiadanie lub 
Wydaje się, że uzasadniona jest konkluzja ostateczna (choć w pewnym sensie też prowizoryczna), iż aspektem nadrzędnym, scalającym treść zdań wchodzących z konieczności do teologii moralnej, jest etyczna wartość postępowania ludzkiego. Wartość ta przy tym jest nierozdzielnie związana w większości przypadków działania ludzkiego z pojęciem powinności etycznej, mianowicie wszędzie tam, gdzie wchodzi w grę działanie mające ujawniać zgodność z elementami podstawowymi osoby ludzkiej. Wartość ta - lub być może lepiej: wartościowość - ujawnia się zarówno w zakresie tego, co w oświetleniu teologicznym ukazane jest jako powinność w ścisłym sensie, jak też w zakresie tego, co jest przedmiotem „doskonałości”, wezwania specjalnego, wzniosłości etycznej. Przyjęcie aspektu wartości jako nadrzędnego prowadziłoby do zdefiniowania teologii moralnej jako nauki o wartości etycznej ludzkiego działania $\mathrm{w}$ świetle poznania teologicznego. To ostatnie wyrażenie przy tym implikuje właściwy udział elementu wiedzy ludzkiej, zgodnie z koncepcją poprawnej, pełnej wiedzy teologicznej ${ }^{35}$.

Aspekt wartości etycznej pozwala na scalenie w obrębie teologii moralnej dwóch innych kategorii zdań, to jest zdań wchodzących w skład tak zwanej etyki opisowej i wchodzących w skład etyki normatywnej. Pierwsze $z$ nich składają się na opis zjawiska moralnego, to znaczy jego treści uchwytnej w bezpośrednim przeżyciu, jego form ujawnienia się $\mathrm{w}$ postawach i działaniu ludzkim jednostkowym i zbiorowym, zwłaszcza $\mathrm{w}$ postaci norm uznanych społecznie i utrwalonych $\mathrm{w}$ piśmie lub $\mathrm{w}$ tradycji ustnej.

Ta wiedza częściowo ma znaczenie dla samego określenia wartościowania etycznego (introspekcja), częściowo zaś służy za pomocniczy wskaźnik przy poszukiwaniu wartości konkretnych działań ludzkich. Etyka opisowa zatem w pewnym zakresie tworzy składową część wiedzy warunkującej powstanie etyki normatywnej. Wraz z nią może być określana mianem etyki, ponieważ i jedna i druga ma za przedmiot wartościowanie etyczne: pierwsza od strony uzasadnienia i treści, druga od strony przejawów ${ }^{36}$.

nieposiadanie pewnych cech uznanych za kryterium oceny, takich na przykład jak zgodność z regułą postępowania lub doskonalszy sposób wypełnienia założonego ideału postępowania. Wysunięcie na pierwszy plan aspektu wartości pozwala scalić w systemie etycznym poprawność postępowania i doskonałość postępowania. Nie uchyla jednak bynajmniej charakteru normatywnego etyki, ponieważ realizacja tego, co „wartościowe" ukazuje się, przynajmniej w pewnym zakresie, jako obowiązek.

${ }_{35}$ Por. Y. Congar, Wiara i teologia, w: Tajemnica Boga, tłum. o. B. Przybylski, Poznań, 1967.

${ }_{36}$ Jeśli jako punkt wyjścia etyki obiera się samo zjawisko moralne i analizuje się je, a następnie wyjaśnia, poszukując jego najglębszych i ostatecznych, tłumaczących je racji, to wówczas przyjmuje się przynajmniej niektóre elementy etyki opisowej jako konieczne składniki wiedzy etycznej w jej szerokim znaczeniu. Por. 
Wśród wskazanych w inwentarzu zdań zachodzi poza tym inny podział o zasadniczym znaczeniu. Jest to podział na zdania o treści uzyskanej drogą wyłącznie rozumową i zdania o treści objawionej. Treść tych dwóch kategorii zdań $w$ pewnym zakresie pokrywa się lub pozostaje w takim stosunku, że zdania należące do Objawienia wyrażają w języku właściwym źródłom objawionym (alegorycznym, symbolicznym) treść, która może być dzięki refleksji teologicznej ujęta w terminach jednoznacznych lub analogicznych i uznana za szczególne, autorytatywne potwierdzenie wiedzy rozumowej ${ }^{37}$.

W wielu przypadkach jednak treść tych dwóch kategorii zdań nie pokrywa się. Objawienie wnosi do zakresu informacji ważnych dla wartościowania etycznego takie, które nie mogą występować w zakresie rozumowej wiedzy etycznej ${ }^{38}$. Ma to istotne znaczenie dla wyboru aspektu scalającego całokszałt teologii moralnej. Wybór aspektu wartościowania etycznego właściwego etyce rozumowej, nie znajdującego odpowiednika w zakresie wiedzy etycznej objawionej, spowoduje wyłączenie z zakresu teologii moralnej szeregu elementów dla tej wiedzy istotnych i charakterystycznych (np. wezwanie do doskonałości, pewne typy motywacji). Również odwrotnie - wybór aspektu wartościowania etycznego charakterystyczny i właściwy Objawieniu, nie znajdujący odpowiednika w etyce rozumowej spowoduje, że wiele dziedzin działania ludzkiego nie zostanie objętych oceną i normowaniem, ponieważ dziedziny te nie są przedmiotem pouczeń etycznych Objawienia wprost, ani też nie zostaną naświetlone $\mathrm{z}$ tego stanowiska, skoro wobec obranego aspektu wartościowania nie znajdą się w polu uwagi. Może to mieć miejsce zwłaszcza przy bardzo wąskim pojmowaniu treści takich idei jak ,zbawienie", ,naśladowanie” itp ${ }^{39}$.

Ponieważ w treści Objawienia znajdują się informacje oraz dyrektywy wychodzące poza zakres wiedzy etycznej rozumowej, należy poszu-

K. St. Kamiński, O różnych rodzajach wiedzy o morainości, „Studia Theol. Varsaviensia", 6 (1968), nr 1, ss. 193-204.

37 Dotyczy to zarówno zdań teoretycznych (egzystencjalnych, opisowych), jak i zdań będących ocenami lub normami. Częściowe zachodzenie na siebie zakresów zdań normatywnych ma tu miejsce w dziedzinie norm tworzących przepisy (reguły) prawa naturalnego. Sa one przedmiotem czysto naturalnej wiedzy etycznej, a jednocześnie znajdują potwierdzenie ze strony Objawienia co do ich mocy wiążącej, wzięte jako całość lub jako ogólna, podstawowa zasada moralna. Niektóre zaś skonkretyzowane przepisy prawa naturalnego są jednocześnie przedmiotem pouczenia moralnego zawartego w Objawieniu wprost, lub wynikającego $\mathrm{z}$ faktów poznanych z Objawienia.

38 Odnosi się to zwlaszcza do taki pouczeń moralnych Objawienia, które w świetle tajemnic wiary - zwłaszcza w świetle tajemnicy Zbawienia oraz ostatecznego przeznaczenia człowieka i świata - kształtują niejako „obyczaje” człowieka odrodzonego przez laskę i oczekującego ostatecznego spełnienia odwiecznych planów Bożych.

${ }_{33}$ Por. R. Schnackenburg, Die Sittliche Botschaft des Neuen Testamentes, München, ${ }^{2} 1962$. 
kiwać aspektu wartościowania etycznego, scalającego całokształt teologii moralnej nie wśród zasobu pojęć etyki rozumowej, lecz wśród pojęć właściwych wiedzy etycznej zaczerpniętej $\mathrm{z}$ danych objawionych ${ }^{40}$. Aspekt ten może się okazać właściwy wtedy, gdy swą treścią wiąże się zarówno z normatywnym znaczeniem natury ludzkiej, z jej aspektem osobowym i społecznym, jak też $\mathrm{z}$ faktycznym stanem człowieka jako takiego i $z$ jego nadnaturalnym ubogaceniem. Obranie tego rodzaju aspektu jako nadrzędnego pozwoli formułować oceny i dyrektywy, (zarówno w postaci norm, jak i zaleceń, wezwań), odniesione do wszelkich możliwych dziedzin ludzkiej działalności, a zarazem podatne na modyfikacje, jakie, wciąż w tym samym aspekcie może wnosić indywidualne wezwanie Boże i wzbudzane przez Niego poczucie konieczności maksymalnego daru ze siebie jako wymagania miłości.

Wydaje się, iż tego rodzaju aspekt można wskazać - wykraczając na tym punkcie poza ścisłe ramy zakreślonego tu zadania — w biblijnej idei ,powołania”, pojętego jako wyposażenie naturalne człowieka (w akcie stwórczym) i udarowanie nadprzyrodzone (w akcie zbawczym), zobowiązujące do działania zgodnego $z$ naturą i nadnaturalnym wezwaniem do zjednoczenia z Bogiem przez miłość.

\section{R E S U M E}

\section{LE PROBLEME DE L'UNITÉ DE LA THÉOLOGIE MORALE}

La théologie morale d'aujourd'hui a besoin de retrouver son unité. On lui reproche de ne pas avoir réussi dans sa forme traditionnelle à intégrer suffisamment l'élément philosophique dans son contenu révélé sans introduire des modifications, qui rendent ce contenu moins riche et dans quelque sens limité aux catégories morales laiques.

Les courants, qui se développaient en théologie morale déjà au XIXe siècle et ont trouvé dans quelque sens leur approbation officielle de I'Eglise, c. à d. la méthode néo-scolastique et la méthode pastorale - biblique (Sailer, Hirscher, Tillmann, Häring) - la première dans le passé et la seconde tout récemment dans la doctrine du Vatican II - font voir divers aspects du comportement moral, irréductibles les uns aux autres, qui doivent être envisagés dans la conception correcte de la morale chrétienne.

40 Odpowiada to postulatowi wysuwanemu $\mathrm{w}$ teologii, by treść będąca przedmiotem tej nauki możliwie ściśle odpowiadała treści, jaką Bóg ujawnił w Objawieniu o Sobie i o człowieku. W tym sensie etyka chrześcijańska ma być przede wszystkim wiedzą normującą ludzkie działanie w tych dziedzinach i w taki sposób, jak to wynika z zamiarów Boga względem człowieka, poznanych z Objawienia. 
Mais l'exigence méthodologique indispensable, qui doit être respectée en premier lieu, c'est que chaque science doit envisager ses énoncés sur un objet donné sous un aspect strictement determiné. C'est qui fait surgir le problème de trouver un aspect spécifique de la théologie morale considérée comme la morale théologique.

La théologie morale est constituée comme science par deux genres des propositions: pratiques (normatives) et théoriques (descriptives, existentielles). Ces dernières appartiennent aux divers genres des sciences humaines, l'anthropologie métaphysique y comprise. Ils constituent en morale théologique la base empirique et métaphysique pour les propositions normatives, aussi que les propositions révélées constituent le fondement pour les normes morales révélées. Il faut alors retrouver un tel aspect, qui pourrait étre commun pour toutes propositions normatives en théologie morale et de même servir pour un critère de choix des propositions descriptives.

I'inventaire complet des propositions, qui composent le contenu de la théologie morale fait voir, que ce n'est pas la fin, qui constitue l'aspect unique et principal, mais c'est l'aspect de la valeur morale et de la perfection, liés avec l'obligation morale. Cet aspect peut prendre sa forme concrète dans le langage biblique sous le nom de „vocation" et comme tel peut redonner à la théologie morale son unité nécessaire. 